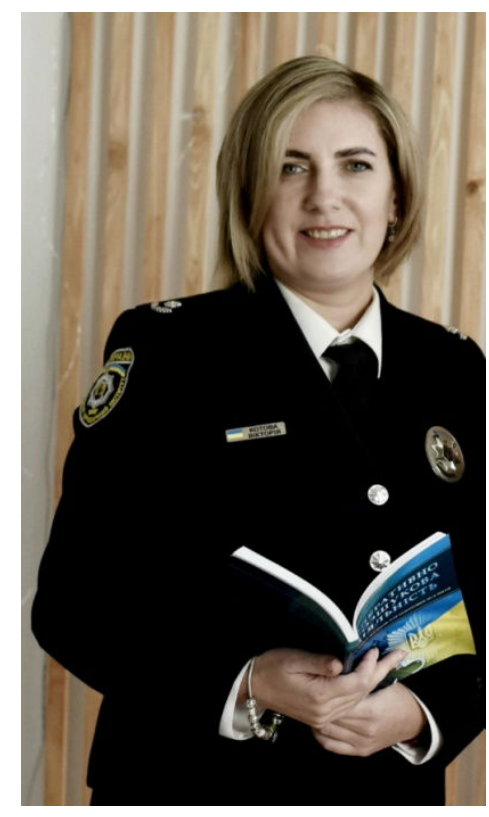

Котова Вікторія Валеріївна, кандидат юридичних наук (Донецький державний університет внутрішніх справ, м. Маріуполь) ORCID: https://orcid.org/0000-0003-2046-2635

\title{
ЗАБЕЗПЕЧЕННЯ БЕЗПЕКИ ОСІБ, ЯКІ ВИКОНУЮТЬ СПЕЦІАЛЬНЕ ЗАВДАННЯ
}

У статті визначено дефініцію ефективності забезпечення безпеки осіб, які виконують спеціальне завдання з розкриття злочинної діяльності організованої групи, та окреслено основні напрями підвищення ефективності забезпечення безпеки осіб, які виконують спеціальне завдання, зокрема такі: поліпшення правил застосування заходів забезпечення безпеки; удосконалення змісту підстав та прочесуального порядку забезпечення безпеки; скорочення часових меж застосування заходів забезпечення безпеки; розширення видів заходів безпеки; покращення фінансування та матеріально-технічного забезпечення заходів безпеки.

Ключові слова: безпека; забезпечення безпеки учасників кримінального судочинства; особа, яка виконує спечіальне завдання; свідок; негласні слідчі (розшукові) дї;; заходи забезпечення безпеки; ефективність.

Постановка проблеми. Передбачені законодавством заходи забезпечення безпеки щодо учасників кримінального судочинства вживають для того, щоб досягти мети попередити або припинити протиправні посягання стосовно осіб, які перебувають під захистом. А це означає, що такі заходи мають бути ефективними. Інститут забезпечення безпеки особи, яка виконує спеціальне завдання 3 розкриття злочинної діяльності організованої групи або злочинної організації, покликаний захистити цих осіб, оскільки їм може загрожувати небезпека під час кримінального процесу, а в більшості випадків - i після його закінчення.

Тому $є$ доцільним, перш ніж визначити напрями підвищення ефективності забезпечення безпеки особи, що виконує спеціальне завдання $з$ розкриття злочинної діяльності організованої групи або злочинної організації, з'ясувати дефініцію ефективності забезпечення безпеки та основні напрями їі підвищення.

Аналіз останніх досліджень і публікацій. Деякі аспекти забезпечення безпеки осіб у кримінальному провадженні досліджували такі науковці: О. М. Бандурка, В. І. Галаган, О. О. Гриньків, О. Ю. Спіхін, Є. В.Жаріков, О. О. Зайцев, В. С. Зеленецький, Б. М. Качмар, М. В. Куркін, О. В. Левченко, А. О. Ляш, В. І. Маринів, А. М. Орлеан, М. В. Новікова, С. М. Пашков, Т. І. Панасюк, Н. В. Пелипенко, М. А. Погорецький, П. В. Серебрянський, В. Ю. Шепітько, М. Є. Шумило, А. А. Юнусов та інші. До того ж учені розглядали лише загальні питання забезпечення безпеки учасників кримінального процесу. На жаль, дослідженню гарантій безпеки осіб, які виконують спеціальне завдання з розкриття злочинної діяльності організованої групи чи злочинної організації, науковці не приділяли достатньої уваги.

Виклад основного матеріалу. У словнику української мови термін «ефективність» (з лат. effertus - «результат») визначається як «наслідок чого-небудь», складовими якого $\epsilon$ доцільність (відповідність діяльності поставленій меті), раціональність (розсудливість у використанні наявних сил і засобів) та продуктивність (досягнення бажаного результату); 
ефективний, тобто такий, який приводить до потрібних результатів, наслідків, дає найбільший ефект [1, с. 492].

П. М. Рабінович помічає, що загальна ефективність правового впорядкування забезпечується ефективністю: а) самого нормативно-правового акта; б) процедурнопроцесуального механізму застосування нормативно-правового акта; в) діяльності щодо використання та реалізації нормативно-правового акта. Таким чином, в одних випадках ефективність норми забезпечується лише за рахунок іiї власної дії, в інших - у результаті дії системи «норма плюс іiї застосування» [2, с. 158].

Одним із факторів зниження активності громадян у сприянні кримінальному судочинству, на наше переконання, $\epsilon$ нівелювання соціального престижу надання органам дізнання, досудового слідства та суду потрібної та об'єктивної інформації щодо вчинення злочинів й інших правопорушень. Побоюючись помсти з боку представників злочинного середовища, громадяни не вірять у спроможність відповідних органів захистити їх від протиправних посягань i, як наслідок, уникають співпраці 3 органами, наділеними повноваженнями з протидії злочинності.

П. М. Рабінович розрізняє юридичну та загальну ефективність правового регулювання [2, с. 150-151].

Про юридичну ефективність ідеться, коли в результаті прийняття нормативноправового акта настають саме юридичні наслідки, що пов'язані із внесенням змін до правового становища окремого суб'єкта чи групи осіб. Загальна ефективність передбачає реальні зміни в різних сферах суспільних відносин, які відбуваються в результаті впровадження нормативно-правового акта в практичну діяльність.

Проведене нами опитування серед працівників слідчих та оперативних підрозділів 3 теорії та практики застосування норм, що належать до інституту забезпечення безпеки осіб, які виконують спеціальне завдання з розкриття злочинної діяльності організованої групи чи злочинної організації,доводить той факт, що більшість осіб відмовляються від заходів забезпечення безпеки, мотивуючи це недовірою до правоохоронних органів.

Зневіра з боку осіб, що виконують спеціальне завдання з розкриття злочинної діяльності організованої групи або злочинної організації, які під впливом страху погоджуються давати свідчення, але з обов'язковим застосуванням такого заходу безпеки, як гарантування конфіденційності відомостей про особу. На практиці це відбувається шляхом заміни прізвища, імені та імені по батькові. За таких обставин потрібно змінювати й місце проживання та інші дані про особу, що унеможливлюють іiї ідентифікацію. Однак це часто ігнорується 3 боку працівників правоохоронних органів або проявляється у вигляді недбалості. Тим самим створюється загроза для життя і здоров'я особи, узятої під захист.

Слушною $\epsilon$ думка про правомірність напрямів підвищення ефективності забезпечення безпеки як суб' єктам кримінального процесу загалом, так і особі, що виконує спеціальне завдання. Зокрема, В. С. Зеленецький і М. В. Куркін уважають, що до чинників, які зумовлюють ефективність використання тактичних прийомів реалізації заходів безпеки стосовно осіб, які підлягають захисту, належать:

a) функціональна підготовленість оперативних працівників для розробки ефективних тактичних прийомів оптимального застосування заходів забезпечення безпеки суб'єктів кримінального процесу;

б) ситуативний підхід до опрацювання оптимальних тактичних прийомів ефективного здійснення заходів забезпечення безпеки;

в) повнота й достовірність відомостей про осіб, що створюють загрозу безпеці суб'єктів кримінального процесу, для підготовки та використання ефективних тактичних способів захисту цих суб'єктів;

г) знання середовища функціонування правоохоронних органів для розробки та застосування прийнятних тактичних прийомів ужиття заходів із забезпечення безпеки; 
г) адекватність поведінки осіб, які потребують захисту, для винайдення ефективних способів забезпечення безпеки;

д) розроблення тактичних прийомів реалізації заходів забезпечення безпеки 3 урахуванням специфіки суб'єктного складу злочинних груп;

е) істинність знань про способи та засоби скоєння злочинів для створення належних тактичних прийомів застосування засобів забезпечення безпеки в різних ситуаціях боротьби зі злочинністю [3, с. 42].

Аналіз наукової літератури свідчить про певний рівень уваги до кримінальних, процесуальних та оперативно-розшукових напрямів підвищення ефективності забезпечення безпеки учасників кримінального судочинства та недостатню увагу вчених до криміналістичних аспектів забезпечення безпеки учасників кримінального судочинства. Нечисленні праці відображають переважно проблеми анонімності допиту свідків, рекомендації з тактичних особливостей допиту, упізнання в режимі відеоконференції. У криміналістичному забезпеченні розслідування злочинів виокремлюють технікокриміналістичне, тактико-криміналістичне та методико-криміналістичне забезпечення [4, с. 4].

Безсумнівно, зазначені складові можуть стати підгрунтям для формування напрямів підвищення ефективності забезпечення безпеки особи, що виконує спеціальне завдання.

Так, техніко-криміналістичний напрям підвищення ефективності охоплюватиме розробку або/і вдосконалення наукових засад та криміналістичних рекомендацій застосування спеціальних технічних засобів і методів їхнього використання в забезпеченні безпеки осіб, зокрема електронно-обчислювальної техніки (комп'ютери), відеокамер, охоронних систем, систем відеоспостереження, електронних браслетів тощо. До того ж $є$ необхідність опрацювання тактичних рекомендацій із питань підготовки та проведення слідчих (розшукових) дій за допомогою осіб, стосовно яких проводяться заходи безпеки (наприклад, слідчий та інші особи, що братимуть участь у негласних слідчих (розшукових) діях (далі - НС(Р)Д) разом з особою, яка захищається, мають бути обізнані та зобов'язані дотримуватися певних заходів безпеки: не повідомляти сторонніх про час та місце проведення НС(Р)Д, відключити функцію геопросторового визначення місця знаходження на своїх мобільних телефонах, транспортних засобах тощо). У зв'язку з особливим психологічним станом викривачів, очевидців і постраждалих, щодо яких злочинці вдаються до залякувань i погроз, маючи на меті примусити їх відмовитися від обвинувачення, та подальшим застосуванням заходів забезпечення безпеки, у тому числі пов'язаних зі зміною місця проживання, роботи чи навчання, убачається доцільним залучення психологів як до участі в проведенні слідчих (розшукових) дій, так і до роботи 3 ними взагалі.

Методико-криміналістичне забезпечення безпеки учасників кримінального судочинства, на наш погляд, включатиме розробку методичних рекомендацій із питань таких особливостей розслідування окремих видів злочинів, що зумовлюються забезпеченням безпеки осіб. Уважаємо, що зазначені методико-криміналістичні рекомендації відображатимуть особливості взаємодії правоохоронних органів у процесі забезпечення безпеки учасників кримінального судочинства та використання спеціальних знань, співпраці з національними державними установами, правоохоронними органами інших країн тощо. Водночас наведені криміналістичні рекомендації можуть стати структурним компонентом методик розслідування окремих видів злочинів, наприклад корупційних, злочинів проти національної безпеки та ін.

3 позиції практичності, на думку Б. М. Качмаря, важливим повинно бути документальне фіксування правовідносин між суб'єктом кримінального провадження, який потребує захисту, і тим, хто такий захист повинен забезпечити.

Вирішенням порушених питань міг би стати порядок, завдяки якому встановлення правовідносин у сфері забезпечення безпеки учасника кримінального провадження має відбуватися у формі угоди, у якій чітко повинні бути окреслені такі складові, як: 
а) предмет угоди; у якому кримінальному провадженні вона укладається; дата та місце укладення;

б) понятійний апарат угоди (зокрема, треба чітко визначити, що таке «невиконання особою умов заходів безпеки», «систематичне невиконання законних вимог органів, що забезпечують безпеку», «благо (життя, здоров’я, майно, законний інтерес), що підлягає захисту»);

в) конкретні заходи безпеки, що застосовуються до особи, та їхня тривалість;

г) права та обов'язки осіб, щодо яких здійснюються заходи забезпечення безпеки; права та обов'язки органів, які забезпечують безпеку;

г) юридична відповідальність за порушення умов угоди, зокрема в разі відмови від співпраці;

д) конкретна особа органу, яка забезпечує безпеку та відповідає за комунікацію з особою, щодо якої вживаються заходи безпеки, та засоби зв'язку;

е) відомості щодо конфіденційності та місця зберігання угоди;

є) порядок оскарження недотримання зобов'язань за угодою;

ж) реквізити сторін угоди [5, с. 142-143].

М. Л. Грібов та О. І. Козаченко вказують, що норми ст. 11 Закону України «Про оперативно-розшукову діяльність» [6] не мають механізму їхньої реалізації через брак відповідних зв'язків із трудовим і податковим законодавством, а також із законодавством про державну таємницю. Так, ч. 3 ст. 24 Кодексу законів про працю України [7] передбачено, що працівник не може бути допущений до роботи без підписання трудового договору, оформленого наказом чи розпорядженням власника або уповноваженого ним органу, і повідомлення центрального органу виконавчої влади 3 питань забезпечення формування та реалізації державної політики 3 адміністрування єдиного внеску на загальнообов'язкове державне соціальне страхування про прийняття працівника на роботу в порядку, установленому Кабінетом Міністрів України [8, с. 12].

Відповідно до пп. 3 і 4 ч. 1 ст. 8 Закону України «Про державну таємницю», до такої таємниці належать відомості про осіб, які співпрацюють або раніше співпрацювали на конфіденційній основі з органами, що проводять оперативно-розшукову, розвідувальну та контррозвідувальну діяльність [9].

Отже, підписати 3 ними договір, зокрема оформлений наказом чи розпорядженням власника або уповноваженого ним органу, згідно з яким можна було б зарахувати термін негласного співробітництва до загального трудового стажу, можливо лише з наданням їм відповідного грифа секретності. Те саме стосується і повідомлення центрального органу виконавчої влади 3 питань забезпечення формування та реалізації державної політики 3 адміністрування єдиного внеску на загальнообов'язкове державне соціальне страхування.

Особи, які виконують спеціальне завдання, не є суб'єктами, відповідальними за збереження державної таємниці, тому й не можуть бути притягнуті до кримінальної або адміністративної відповідальності за іiі розголошення. Такий незатверджений статус унеможливлює притягнення їх навіть до дисциплінарної відповідальності. Водночас вони фактично є носіями державної таємниці. Отже, і цей елемент механізму правового регулювання негласного співробітництва, згідно зі ст. 11 Закону України «Про оперативно-розшукову діяльність», не може бути визнаний ефективним.

Найбільш радикальними напрямами розв'язання окреслених проблем М. Л. Грібов та О. І. Козаченко пропонують такі (до речі, конкурують між собою):

a) запровадження для осіб, які виконують спеціальне завдання, окремої системи оподаткування, урахування трудового стажу та внесків на загальнообов'язкове державне соціальне страхування i нарахування пенсій для негласних співробітників (із забезпеченням необхідного режиму секретності);

б) повне виведення інституту негласного співробітництва зі сфери трудових відносин і перенесення його у сферу цивільних відносин (договірного права) з одночасною 
регламентацією неможливості оподаткування матеріальної винагороди, що виплачується негласним співробітникам [8, с. 12].

Стосовно цього можна констатувати, що для ефективного забезпечення безпеки потрібно покращувати фінансування та матеріально-технічне забезпечення заходів безпеки осіб, які виконують спеціальне завдання з розкриття злочинної діяльності організованої групи або злочинної організації.

Поділяємо думку Д. С. Припутня, що для злагодженої взаємодії між приватними організаціями та правоохоронними структурами необхідними $є$ опрацювання спільних документів під час вивчення об'єктів, які підлягають захисту, та інструктування особового складу територіальних підрозділів, оскільки перебування на охоронюваних об'єктах повітряного транспорту засвідчило, що відсутність нормативних актів, на підставі яких здійснюється взаємодія, збільшує термін підготовки підрозділів для проведення запланованих заходів, що негативно впливає на психологічний стан особового складу підрозділів та ефективність службової діяльності загалом. Для цього науковець пропонує розробити та запровадити Методичні рекомендації «Дії працівників приватних охоронних структур у сфері забезпечення безпеки фізичних осіб та охорони права власності й окремих підрозділів поліції при протидії правопорушенням та розкритті злочинів» [10, c. 32].

Висновки. 3 огляду на викладене, ефективність забезпечення безпеки осіб, які виконують спеціальне завдання з розкриття злочинної діяльності організованої групи або злочинної організації, слід розуміти як створення протягом мінімального терміну часу та 3 урахуванням дотримання прав і свобод людини необхідних безпечних умов для належного виконання спеціального завдання, що має на меті документування злочинної діяльності організованої групи чи злочинної організації.

Основними напрямами підвищення ефективності забезпечення безпеки осіб, які виконують спеціальне завдання з розкриття злочинної діяльності організованої групи або злочинної організації, можна вважати такі:

- поліпшення правил застосування заходів забезпечення безпеки осіб, які виконують спеціальне завдання з розкриття злочинної діяльності організованої групи або злочинної організації;

- удосконалення змісту підстав та процесуального порядку забезпечення безпеки осіб, які виконують спеціальне завдання 3 розкриття злочинної діяльності організованої групи або злочинної організації;

- скорочення часових обмежень реалізації заходів забезпечення безпеки осіб, які виконують спеціальне завдання з розкриття злочинної діяльності організованої групи або злочинної організації;

- $\quad$ розширення видів заходів безпеки, що вживаються щодо осіб, які виконують спеціальне завдання з розкриття злочинної діяльності організованої групи або злочинної організації;

- покращення фінансування та матеріально-технічного забезпечення заходів безпеки осіб, які виконують спеціальне завдання 3 розкриття злочинної діяльності організованої групи або злочинної організації.

\section{Список використаних джерел}

1. Словник української мови : в 11 т. АН УРСР. Інститут мовознавства І. К. Білодіда та ін. К. : Наукова думка, 1970-1980. Т. 6. С. 492.

2. Рабінович П. М. Основи загальної теорії права та держави : навчальний посібник. Вид. 5-те, зі змінами. Київ : Атіка, 2001. 176 с.

3. Зеленецький В., Куркін М. Основні положення вчення про забезпечення безпеки суб'єктів кримінального процесу, що ведуть боротьбу з організованою злочинністю. Прокуратура. Людина. Держава. К. : Істина, 2004. № 4 (34). С. 37-42. 
4. Чорноус Ю. М. Криміналістичне забезпечення розслідування злочинів : монографія. Вінниця : ТОВ «Нілан-ЛТД», 2017. 492 с.

5. Качмар Б. М. Механізм забезпечення безпеки осіб, які беруть участь у кримінальному судочинстві (кримінальний процесуальний аспект) : дис. ... канд. юрид. наук : 12.00.09. Харків, 2017. $198 \mathrm{c}$.

6. Закон України «Про оперативно-розшукову діяльність» від 18.02.1992 № 135-XII. URL: http://zakon4.rada.gov.ua/laws/show/2135-1 (дата звернення: 10.11.2021).

7. Кодекс законів про працю. URL: https://zakon.rada.gov.ua/go/322-08 (дата звернення: 10.11.2021).

8. Грібов М., Козаченко О. Шляхи вдосконалення правового регулювання негласного співробітництва. Науковий вісник Національної академії внутрішніх справ. 2020. № 115 (2). С. 8-18. URL: https://doi.org/10.33270/01201152.8 (дата звернення: 10.11.2021).

9. Закон України «Про державну таємницю». URL: http://search.ligazakon.ua/1_doc2.nsf/link1/ed_1994_01_21/T385500.html (дата звернення: 10.11.2021).

10. Припутень Д. С. Взаємодія приватних охоронних структур з правоохоронними органами та громадськістю у сфері забезпечення безпеки фізичних осіб та охорони права власності. Науковий вісник Ужсгородського національного університету. Серія: Право. 2015. Вип. 30 (2). 68 с.

\section{References}

1. Slovnyk ukrainskoi movy: v $11 \mathrm{t}$. AN URSR. Instytut movoznavstva I. K. Bilodida ta in. [Dictionary of the Ukrainian language]. K. : Naukova dumka, 1970-1980. T. 6. S. 492 [in Ukrainian].

2. Rabinovych, P. M. (2001). Osnovy zahalnoi teorii prava ta derzhavy: navchalnyi posibnyk [Fundamentals of the general theory of law and the state: a textbook]. Vyd. 5-te, zi zminamy. Kyiv: Atika. 176 s. [in Ukrainian].

3. Zelenetskyi, V., Kurkin, M. (2004). Osnovni polozhennia vchennia pro zabezpechennia bezpeky subiektiv kryminalnoho protsesu, shcho vedut borotbu z orhanizovanoiu zlochynnistiu. Prokuratura. Liudyna. Derzhava [The main provisions of the doctrine of ensuring the security of the subjects of criminal proceedings in the fight against organized crime. Prosecutor's office. Man. State]. K. : Istyna. № 4 (34). S. 37-42 [in Ukrainian].

4. Chornous, Yu. M. (2017). Kryminalistychne zabezpechennia rozsliduvannia zlochyniv : monohrafiia [Forensic support of crime investigation: monograph]. Vinnytsia : TOV «Nilan-LTD». $492 \mathrm{~s}$. [in Ukrainian].

5. Kachmar, B. M. (2017). Mekhanizm zabezpechennia bezpeky osib, yaki berut uchast u kryminalnomu sudochynstvi (kryminalnyi protsesualnyi aspekt) : dys. ... kand. yuryd. nauk : 12.00.09 [The mechanism of ensuring the safety of persons involved in criminal proceedings (criminal procedural aspect) : dis. ... cand. jurid. science : 12.00.09]. Kharkiv. 198 s. [in Ukrainian].

6. Zakon Ukrainy «Pro operatyvno-rozshukovu diialnist» vid 18.02.1992 № 2135-XII [Law of Ukraine "On operational and investigative activities" of 18.02.1992 № 2135-XII]. URL: http://zakon4.rada.gov.ua/laws/show/2135-1 (data zvernennia: 10.11.2021) [in Ukrainian].

7. Kodeks zakoniv pro pratsiu [Code of Labor Laws]. URL: https://zakon.rada.gov.ua/go/322-08 (data zvernennia: 10.11.2021) [in Ukrainian].

8. Hribov, M., Kozachenko, O. (2020). Shliakhy vdoskonalennia pravovoho rehuliuvannia nehlasnoho spivrobitnytstva. Naukovyi visnyk Natsionalnoi akademii vnutrishnikh sprav [Ways to improve the legal regulation of covert cooperation]. № 115 (2). S. 8-18. URL: https://doi.org/10.33270/01201152.8 [in Ukrainian].

9. Zakon Ukrainy «Pro derzhavnu taiemnytsiu» [Law of Ukraine "On State Secrets"]. URL: http://search.ligazakon.ua/1_doc2.nsf/link1/ed_1994_01_21/T385500.html (data zvernennia 10.11.2021) [in Ukrainian].

10. Pryputen, D. S. (2015). Vzaiemodiia pryvatnykh okhoronnykh struktur z pravookhoronnymy orhanamy ta hromadskistiu u sferi zabezpechennia bezpeky fizychnykh osib ta okhorony prava vlasnosti. Naukovyi visnyk Uzhhorodskoho natsionalnoho universytetu. Seriia: Pravo [Interaction of private security structures with law enforcement agencies and the public in the field of security of individuals and protection of property rights]. Vyp. 30 (2). 68 s. [in Ukrainian]. 
Правовий часопис Аонбасу № 4 (77) 2021

\section{Kotova Victoria, \\ $\mathrm{PhD}$ in Law}

(Donetsk State University of Internal Affairs, Mariupol)

ORCID: https://orcid.org/0000-0003-2046-2635

\section{ENSURING SECURITY OF PERSONS CARRYING OUT A SPECIAL TASK}

The institute of ensuring the security measures to persons carrying out special tasks detecting the criminal activities of an organized group or criminal organization is called to protect these persons, as they may be in danger during the criminal process, and in most cases after its completion. Therefore, it is advisable to find out the definition and main directions of improving the security measures to persons carrying out special tasks detecting the criminal activities of an organized group or criminal organization. The effectiveness of security measures to persons carrying out special tasks detecting the criminal activities of an organized group or criminal organization should be understood as creating in a minimum time and taking into account human rights and freedoms the necessary safe conditions for proper performance of a special task to document criminal activity of an organized group or a criminal organization. The main directions of improving the effectiveness of security measures to persons carrying out special tasks are: improving the rules of application of security measures to persons carrying out special tasks; improving the content of the grounds and procedural procedure for ensuring the safety of persons carrying out special tasks; reduction of time limits for the application of security measures to persons carrying out special tasks; expanding the types of security measures applied to persons carrying out special tasks; improving the financing and logistics of security measures to persons carrying out special tasks. Methodical and forensic security of the security of criminal justice participants, in our opinion, will include the development of methodological recommendations on issues of such peculiarities of investigating certain types of crimes that are determined by the security of individuals. We believe that these methodical and criminology recommendations will reflect the peculiarities of the interaction of law enforcement agencies in the process of ensuring the safety of participants in criminal justice and the use of special knowledge, cooperation with national state institutions, law enforcement agencies of other countries, etc. At the same time, criminalistic recommendations may become a structural component of techniques for investigating certain types of crimes, such as corruption, crimes against national security, etc.

Key words: ensuring of security; special assignment; human rights; pre-trial investigation; investigative (detective, search) actions; covert investigative (detective) actions; measures to ensure.

Надіслано до редколегії 11.11.2021 Рекомендовано до публікації 17.11.2021 